Journal of Health Promotion and Behavior (2017), 2(2): 124-137

https://doi.org/10.26911/thejhpb.2017.02.02.03

\title{
The Influence of Personal Factor, Husband's support, Health Workers and Peers toward the Use of IVA Screening among Women of Reproductive Age in the Regency of Karanganyar
}

\author{
Martini Shoim Wakhidah'), Uki Retno Budi Hastuti²), Yulia Lanti Retno Dewi 3) \\ ${ }^{1)}$ Masters Program of Public Health, Sebelas Maret University, Surakarta \\ 2)Department of Obstetrics and Gynecology, Moewardi Regional General Hospital Surakarta \\ 3)Faculty of Medicine, Sebelas Maret University, Surakarta
}

\begin{abstract}
Background: Cervix cancer has been one of the highest cancer cases and becomes one of the main problems in women's health throughout the world. The percentage of Women of Reproductive Age who performs early cancer detection is an indicator of success for health development. The Regency of Karanganyar is one of the regencies in the Province of Central Java with the percentage of Women of Reproductive Age who perform Visual Inspection with Acetic Acid (IVA) is equal to $5.50 \%$. This percentage is still far below the target that has been set which is $10.00 \%$.

Subjects and Methods: This was an analytic observational study with cross-sectional design. This study was carried out in Regency of Karanganyar. The subjects who had been involved were 150 respondents and these subjects were selected by means of fixed disease sampling. This sampling resulted in 50 cases and 100 controls. The dependent variable was behavior of using IVA screening, while the independent variables were perceived susceptibility, perceived seriousness, perceived benefits, perceived obstacles, husband's support, health workers support, peer support, perceived threats and self-efficacy. In processing the data, the researchers implemented path analysis by means of Stata 13 .

Results: The results of the study showed perceived threats $(b=0.08 ; 95 \% \mathrm{CI}=<0.01$ until $0.16 ; \mathrm{p}=$ 0.043), perceived benefits $(b=0.05 ; 95 \% \mathrm{CI}=<-0.01$ until $0.117 ; \mathrm{p}=0.091)$, perceived obstacles $(\mathrm{b}=$ $-0.49 ; 95 \% \mathrm{CI}=-0.07$ until $0.11 ; \mathrm{p}=0.091)$, self-efficacy $(\mathrm{b}=0.04 ; 95 \% \mathrm{CI}=-0.13$ until $0.11 ; \mathrm{p}=$ $0.125)$, perceived susceptibility $(b=0.23 ; 95 \% \mathrm{CI}=0.11-0.34 ; \mathrm{p}<0.001)$, perceived seriousness $(\mathrm{b}=$ 0.11; CI9 95\%= 0.00 until $0.22 ; \mathrm{p}=0.049)$, husband's support $(b=0.14 ; 95 \% \mathrm{CI}=-0.01$ until 0.29 ; $\mathrm{p}=0.068)$, health workers support $(\mathrm{b}=-0.23 ; 95 \% \mathrm{CI}=-0.54$ until $0.08 ; \mathrm{p}=0.149)$ and peer support ( $b=0.18 ; 95 \% \mathrm{CI}=-0.13$ until $0.51 ; \mathrm{p}=0.256$ ).

Conclusion: There is a direct influence from perceived benefits, perceived obstacles, perceived threats and self-efficacy toward behavior of using IVA screening. Then, there is indirect influence from perceived susceptibility, perceived seriousness, husband's support, health workers support and peer support toward behavior of using IVA screening.
\end{abstract}

Keywords: IVA, HBM, support, path analysis

\section{Correspondence:}

Martini Shoim Wakhidah. Masters Program of Public Health, Sebelas Maret University, Surakarta. Email:afkarshoim_msw@yahoo.com. Mobile: +6285235464812.

\section{BACKGROUND}

Cervix cancer is one of the highest cancer cases and becomes one of the main women's health problems in the world, especially in the developing countries. The introduction of cervix cancer is an important matter because in order to decrease the number of new cancer cases there should preventive efforts and early detection. These preventive efforts and early detection can be performed easier when the risk factors and the cancer symptoms have been recognized. In addition, cancer diagnosis is a frightening matter for patients and might influence their psychological condition. Attention and psycho-social support toward cancer pati- 
Wakhidah et al./ The Influence of Personal Factor, Husband's support, Health Workers and Peers

ents are expected to overcome their psychological pressures and to maintain their life quality (Kemenkes RI, 2015).

The number of women of reproductive age in the Province of Central Java is $6,736,247$ people. Then, the number of women of reproductive age who perform early cervix cancer detection in the Province of Central Java on 2015 was 18,954 people or only $0.30 \%$. This percentage is still far below the target that has been set namely 10.00\%. In the Province of Central Java, the Regency of Karanganyar has the highest percentage of women of reproductive age who perform Visual Inspection with Acetic Acid (IVA) namely $5.50 \%$, followed by the Regency of Klaten (1.49\%), and the City of Magelang (0.84\%). From 18,954 Women of reproductive age who performed IVA test, 1,868 respondents (9.86\%) had been found IVA-positive; this figure is higher than the figure that has been set by the Ministry of Health namely $3.00 \%$. On the other hand, the number of new cases on cervix cancer in 2015 was 1,114 cases (Dinas Kesehatan Provinsi Jawa Tengah, 2015).

According to Health Belief Model theory, individuals will make decisions toward a disease in order to protect themselves by viewing their conditions in terms of vulnerability, severity, benefits and obstacles. In relation to the statement, the new aspect in this study is the use of path analysis.

This study aimed to identify personal and social support factors that influenced behaviors in IVA screening in the Regency of Karanganyar.

\section{SUBJECTS AND METHODS}

\section{Research design}

This was an analytic observational study by quantitative approach, with cross-sectional design and path analysis in order to identify the influence of the dependent variable toward the independent variables.
The study was conducted in the Regency of Karanganyar.

\section{Population and Sample}

The sample was gathered by means of fixed disease sampling; this technique had been a sample gathering technique among the women of reproductive age who performed the screening (the case group) and the women of reproductive Age who did not perform the screening (the control group). This study implemented the comparison ratio 1:2 between the experimental group and the control group; therefore, the number of cases was 50 and the number of control cases was 100.

\section{Research variables}

The dependent variable of this research is behavior of using IVA screening, and the independent variables are perceived susceptibility, perceived seriousness, perceived benefits, perceived obstacles, husband's support, health workers support, peer support and self-efficacy.

\section{Operational Definition}

The operational definition included the respondents's behaviors in performing IVA screening from the beginning of their marriage until the period of study and the measurement tool in the form of questionnaire.

The data scale was categorical $(\mathrm{O}=\mathrm{Not}$ using IVA, 1=Using IVA). Perception of individual vulnerability referred to the women of reproductive age's subjective perception regarding the risk of suffering from cervix cancer and the perceived possibility of not performing IVA screening among them. The more the women of reproductive age perceived that not performing IVA screening might be a risk, the more they would perform IVA screening.

Perception of disease severity referred to the women of reproductive age's perception regarding their consideration toward how severe the organic and social consequences would be if they did not perform 
Journal of Health Promotion and Behavior (2017), 2(2): 124-137

https://doi.org/10.26911/thejhpb.2017.02.02.03

IVA screening. The more the women of reproductive age believed that the consequence would be worse, the more they would perform IVA screening. The questionnaire in measuring this independent variable made use of continuous data. Therefore, the continuous data should be turned into the categorical data $(0=$ low, $<$ mean; $1=$ high, $\geq$ mean).

The women of reproductive age's perceived benefits considered that women of reproductive age would gain benefits only when they attain specific health service. As an example, if they performed the IVA screening then they would decrease the risk of suffering from cervix cancer. The tool for measuring this variable was continuous data questionnaire; therefore, the continuous data should be turned into the categorical data (o=low, <mean; 1=high, $\geq$ mean) for the sake of the analysis.

Perceived obstacles referred to the perception that women of reproductive age would sense obstacles when they performed the IVA screening. The obstacles might be consideration in terms of cost, consideration in terms of psychological consequences (for example: being ashamed of performing the IVA screening) and consideration in terms of physical matters (for example: having to go through a long mile in order to attain the service). This variable was measured by the continuous data scale questionnaire. Therefore, the continuous data should be turned into the categorical data (o=low, <mean; 1=high, $\geq$ mean) for the sake of the analysis.

Husband's support referred to the presence of the support that had been provided by the women of reproductive age's husbands in performing the IVA screening. Husband's support might be in the form emotional, instrumental, appreciative, informational, material and spiritual. This variable was measured by the continuous data scale questionnaire. For the sake of the analysis, the continuous data should be turned into the categorical data ( $0=$ low, $<$ mean; $1=$ high, $\geq$ mean).

Health workers support referred to the presence of support that had been provided by the health workers in order to maintain the patients's health, for example: supporting the patients (the women of reproductive age) in performing the IVA screening. This variable was measured by the continuous data scale questionnaire. Therefore, the continuous data should be turned into the categorical data ( $\mathrm{o}=\mathrm{low}$, $<$ mean; $1=$ high, $\geq$ mean) for the sake of the analysis.

Peer support referred to the support that had been provided by the women of reproductive age's peers in performing the IVA screening. This support might be provided in overcoming the problems, boosting the women of reproductive age's self-confidence and encouraging the women of reproductive age to be more active. This variable was measured by the continuous data scale questionnaire, so the continuous data should be turned into the categorical data (o=low, <mean; 1=high, >mean) for the sake of the analysis.

Self-efficacy referred to individuals's belief regarding their self-capabilities in performing necessary actions or tasks in order to achieve certain results. This variable was measured by the continuous data scale questionnaire, so the continuous data should be turned into the categorical data for the sake of the analysis ( $\mathrm{o}=$ low, <mean; $1=$ high, $\geq$ mean).

Perceived threats referred to the women of reproductive age's encouragement to perform the IVA screening due to the perceived susceptibility and the perceived seriousness. This variable was measured by the continuous data scale questionnaire; therefore, the continuous data should be 
turned into the categorical data $(\mathrm{O}=\mathrm{low},<$ mean; $1=$ high, $\geq$ mean) for the sake of the analysis.

\section{Data Analyzed}

This dependent variable was measured by the continuous-data questionnaire; therefore, the continuous data should be turned into the categorical data ( $\mathrm{o}=$ low, <mean; $1=$ high, $\geq$ mean) for the sake of the analysis.

The data gathering activities were conducted after the researchers explained briefly about the intention and the objecttives of the interview and after the researchers asked for the women of reproductive age's informed consent to be involved into the interview. Then, the researchers performed the interview based on the questionnaire.

The data processing activities involved several steps namely: (1) Editing; this step was conducted in order to re-check the answer completeness in each questionnaire sheet that had been completed by the respondents; (2) Coding; this step was a process of labeling code to the data from each variables; (3) Tabulating; this step was a process of inputting the questionnaire responses that had been provided by the respondents into the master table; (4) Entry data; this step was a process of inputting the data resulted from the coding into the computer for the sake of analysis by means of computer program; and (5) Cleaning data; this step was a process of rechecking the data that had been inputted into the computer program and the process of revising any errors.

For the data processing and analysis, the researchers implemented Stata 13 . The quantitative data analysis was conducted under the univariate analysis in order to display the data in the form of frequency distribution from each variables. These data would be described in frequency and percentage (\%) and also bivariate (Chi square) by means of Confidence Interval (CI) 95\% $(\alpha=0.05)$. This test was conducted in order to identify the relationship between the dependent and the independent variables and the multivariate analysis by means of path analysis was conducted in order to identify the direct and the indirect influence from the independent variables toward the dependent variables.

Path analysis was an analysis technique that had been performed in order to identify the influence of an exogenous variable toward an endogenous variable both directly and indirectly

\section{Reliability}

The reliability in this study was measured by Cronbach's Alpha analysis in which a variable would be considered reliable if the Cronbach's Alpha >0.60 (Penney, 2016). The higher the Cronbach's Alpha was the better (the more consistent) the measurement tool would be. There were several situations in which Cronbach's Alpha did not show a good measurement tool. The Cronbach's Alpha value depended on the size of inter-item correlation and the number of items in a measurement tool. If the number of question items in a measurement tool were abundant, then the Cronbach's Alpha value would increase although the improvement did not imply that the measurement tool had been good.

From the results of reliability test toward perception of individual's vulnerability perception of disease severity, perceived benefits, perceived obstacles, husband's support, peer support, health workers support, perceived threats and self-efficacy, the researchers attained total item correlation $\mathrm{d} \geq 0,20$ for each questionnaires item and Cronbach's Alpha $\geq 0,60$. Furthermore, the researchers used the test results in order to gather the data for the study. In this study, the measurement tool that the researchers implemented in order to mea- 
Journal of Health Promotion and Behavior (2017), 2(2): 124-137

https://doi.org/10.26911/thejhpb.2017.02.02.03

sure the variable's score was questionnaire. The questionnaire contained the questions that would be asked in order to measure the influence of independent variables toward the dependent variable.

Table 1. Results of instrument reliability test on the perceived behavior variables

\begin{tabular}{lcc}
\hline \multicolumn{1}{c}{ Variables } & $\begin{array}{c}\text { Corrected Item-Total } \\
\text { Correlation }\end{array}$ & Cronbach's Alpha \\
\hline Behaviors in performing the IVA & $\geq 0.38$ & 0.79 \\
screening & $\geq 0.27$ & 0.83 \\
Perceived susceptibility & $\geq 0.61$ & 0.82 \\
Perceived seriousness & $\geq 0.72$ & 0.90 \\
Perceived benefits & $\geq 0.51$ & 0.76 \\
Perceived obstacles & $\geq 0.67$ & 0.87 \\
Perceived threats & $\geq 0.54$ & 0.84 \\
Self-efficacy & $\geq 0.56$ & 0.50 \\
Husband's support & $\geq 0.71$ & 0.93 \\
Health workers support & $\geq 0.22$ & 0.79 \\
Peer support & & \\
\hline
\end{tabular}

\begin{tabular}{|c|c|}
\hline RESULTS & raduates. The \\
\hline $\begin{array}{l}\text { 1. Subjects Characteristics } \\
\text { Based on Table } 1 \text {, it was apparent that most } \\
\text { of the subjects }(46.00 \%) \text { were senior/voca- }\end{array}$ & $\begin{array}{l}\text { the subjects }(71.30 \%) \text { were unemployed or } \\
\text { were housewives. In terms of marital sta- } \\
\text { tus, all subjects had been married. }\end{array}$ \\
\hline
\end{tabular}

Table 2. Subjects' characteristics

\begin{tabular}{clcc}
\hline No & \multicolumn{1}{c}{ Classification } & n & \% \\
\hline \multirow{2}{*}{1} & Education & & \\
& Primary School & 16 & 10.60 \\
& Secondary School & 29 & 19.30 \\
& Senior/Vocational High School & 69 & 46.00 \\
& Associate Degree & & \\
& Bachelor's Degree & 12 & 8.00 \\
& Master Degree & 23 & 15.30 \\
& Employment & 1 & 0.60 \\
2 & Unemployed & & \\
& Employed & 107 & 71.30 \\
& Marital status & 43 & 28.60 \\
3 & Married & & 100.00 \\
& Not Married & 150 & 0,00 \\
\hline
\end{tabular}

\section{Univariate Analysis}

The results of univariate analysis displayed in Table 3 showed the data regarding perceived threats, perception of benefit, perceived obstacles, self-efficacy, perceived susceptibility, perceived seriousness, husband's support, health workers support and peer support on the behavior of using IVA screening.
Based on the results displayed in table 3 as well, the researchers found that the percentage of behaviors of using IVA had been low while the percentage of perceived susceptibility, perceivev seriousness, perceived benefits, perceived obstacles, husband's support, health workers support, peer support, perceived threats and self-efficacy had been higher. 
Table 3. Univariate analysis toward personal factors, husband's support, health workers support and peer support toward the use of iva screening among women of reproductive age in the Regency of Karanganyar

\begin{tabular}{|c|c|c|c|}
\hline No & Classification & $\mathbf{n}$ & $\%$ \\
\hline \multirow[t]{3}{*}{1} & Behaviors of using IVA & & \\
\hline & Low & 100 & 66.60 \\
\hline & High & 50 & 33.30 \\
\hline \multirow[t]{3}{*}{2} & Perceived susceptibility & & \\
\hline & Low & 67 & 44.70 \\
\hline & High & 83 & $55 \cdot 30$ \\
\hline \multirow[t]{3}{*}{3} & Perceived seriousness & & \\
\hline & Low & 73 & 48.70 \\
\hline & High & 77 & 51.30 \\
\hline \multirow[t]{3}{*}{4} & Perceived benefits & & \\
\hline & Low & 73 & 48.70 \\
\hline & High & 77 & 51.30 \\
\hline \multirow[t]{3}{*}{5} & Perceived obstacles & & \\
\hline & Low & 74 & 49.30 \\
\hline & High & 76 & 50.70 \\
\hline \multirow[t]{3}{*}{6} & Husband's support & & \\
\hline & Low & 68 & $45 \cdot 30$ \\
\hline & High & 82 & 54.70 \\
\hline \multirow[t]{3}{*}{7} & Health workers support & & \\
\hline & Low & 65 & $45 \cdot 30$ \\
\hline & High & 85 & 54.70 \\
\hline \multirow[t]{3}{*}{8} & Peer support & & \\
\hline & Low & 57 & 38.00 \\
\hline & High & 93 & 62.00 \\
\hline \multirow[t]{3}{*}{9} & Perceived threats & & \\
\hline & Low & 70 & 47.70 \\
\hline & High & 80 & 53.30 \\
\hline \multirow[t]{3}{*}{10} & Self-efficacy & & \\
\hline & Low & 46 & 30.70 \\
\hline & High & 104 & 69.30 \\
\hline
\end{tabular}

\section{Bivariate Analysis}

Bivariate analysis explained the influence of one independent variable toward one dependent variable. The variables in this study were behaviors of using IVA, perceived susceptibility, perceived seriousness, perceived benefits, perceived obstacles, husband's support, health workers support, peer support, perceived threats and self-efficacy. The method that the researchers implemented in conducting this study was chisquare with degree of trust $95 \%$ ( $\mathrm{p}$ value= 0.005).

Table 3 showed the data of bivariate analysis regarding the influence of perceived threats, perceived benefits, perceived obstacles, self-efficacy, perceived susceptibility, perceived seriousness, husband's support, health workers support, and peer support toward the behaviors of using IVA. The results of the analysis showed that there had been significant relationship among perceived threats $(\mathrm{OR}=2.189 ; 95 \% \mathrm{CI}=1.08$ until 4.43; $\mathrm{p}=0.037)$, perceived benefits $(\mathrm{OR}=2.173 ; 95 \% \mathrm{CI}=1.08$ until 4.37; $\mathrm{p}=$ o.037) peer support $(\mathrm{OR}=2.591 ; 95 \% \mathrm{CI}=$ 1.21 until 5.54; $\mathrm{p}=0.013$ ) toward behaviors of using IVA.

The results of the analysis, on the other hand, also showed that there had not been any relationship among perceived obstacles $(\mathrm{OR}=1.994 ; 95 \% \mathrm{CI}=0.99$ until 3.99; $\mathrm{p}=0.058)$, self-efficacy $(\mathrm{OR}=1.402$; 95\% CI=0.67 until 2.99; $\mathrm{p}=0.450)$, perceived susceptibility $(\mathrm{OR}=1.941 ; 95 \% \mathrm{CI}=0.96$ until 3.93; $\mathrm{p}=0.081$ ), perceived seriousness 
Journal of Health Promotion and Behavior (2017), 2(2): 124-137

https://doi.org/10.26911/thejhpb.2017.02.02.03

$(\mathrm{OR}=1.915 ; 95 \% \mathrm{CI}=0.96$ until $3.83 ; \mathrm{p}=$ o.083), husband's support (OR=2.020; 95\% CI=0.99 until 4.09; $\mathrm{p}=0.081)$ and health workers support $(\mathrm{OR}=2.042 ; 95 \% \mathrm{CI}$ $=1.00$ until 4.16; $\mathrm{p}=0.056)$ toward the behaviors of using IVA.

Table 4. Bivariate analysis toward personal factors, husband's support, health workers support and peer support toward the behavior of using iva screening among women of reproductive age in the Regency of Karanganyar

\begin{tabular}{lcccc}
\hline \multirow{2}{*}{ Independent Variables } & \multirow{2}{*}{ OR } & \multicolumn{2}{c}{ 95\% CI } & \multirow{2}{*}{ P } \\
\cline { 3 - 4 } & & Upper Limit & Lower Limit & \\
\hline Perceived threats & 2.18 & 1.08 & 4.43 & 0.037 \\
Perceived benefits & 2.17 & 1.08 & 4.37 & 0.037 \\
Perceived obstacles & 1.99 & 0.99 & 3.99 & 0.058 \\
Self-efficacy & 1.40 & 0.67 & 2.99 & 0.450 \\
Perceived susceptibility & 1.94 & 0.96 & 3.93 & 0.081 \\
Perceived seriousness & 1.91 & 0.96 & 3.83 & 0.083 \\
Husband's support & 2.02 & 0.99 & 4.09 & 0.057 \\
Health workers support & 2.04 & 1.00 & 4.16 & 0.056 \\
Peer support & 2.59 & 1.21 & 5.54 & 0.013 \\
\hline
\end{tabular}

\section{Multivariate Analysis}

The behavior of using IVA screening among women of reproductive age have been influenced by perceived threats, perceived benefits, perceived obstacles and self-efficacy.

The logodd of IVA screening use for women of reproductive age with high perceived threats was 0.08 point higher than that for Women of Reproductive Age with low perceived threats $(b=0.08$; $95 \% \mathrm{CI}=$ 0.00 until $0.01 ; \mathrm{p}=0.043$ ).

The logodd of IVA screening use for women of reproductive age with high perceived benefits was 0.05 point higher than that for women of reproductive age with low perceived benefits $(b=0.05$; 95\% CI=$<0.01$ until $0.11 ; \mathrm{p}=0.091$ ).

The logodd of IVA screening use for women of reproductive age with high perceived obstacles was 0.49 point higher than that for Women of Reproductive Age with low perceived obstacles $(b=-0.49$; $95 \% \mathrm{CI}=$ -0.11 until 0.07; $\mathrm{p}=0.091$ ).

The logodd of IVA screening use for Women of Reproductive Age with high selfefficacy was 0.47 point higher than that for women of reproductive Age with low self- efficacy ( $b=0.47 ; 95 \% \mathrm{CI}=-0.01$ until $0.11 ; \mathrm{p}$ $=0.125$ ).

Perceived threats was influenced by perceived susceptibility, perceived seriousness, husband's support, health workers support and peer support.

The logodd of perceived threats for women of reproductive age with high perceived susceptibility was 0.23 point higher than that for Women of Reproductive Age with low perceived threats $(\mathrm{b}=0.23$; 95\% CI $=0.11$ until $0.34 ; \mathrm{p} \leq 0.001$ ).

The logodd of perceived threats for women of reproductive age with high perceived susceptibility was 0.11 point higher than that for Women of Reproductive Age with low perceived susceptibility $(b=0.11$; 95\% CI $=0.00$ until $0.22 ; \mathrm{p}=0.049$ ),

The logodd of perceived threats for women of reproductive age with high husband's support was 0.14 point higher than that for Women of Reproductive Age with low husband's support $(\mathrm{b}=0.14 ; 95 \% \mathrm{CI}=-$ 0.01 until $0.29 ; \mathrm{p}=0.068$ ).

The log odd of perceived threats for women of reproductive age with high health workers support was 0.23 point higher than that for women of reproductive age with 
low health workers support $(b=-0.23 ; 95 \%$ $\mathrm{CI}=-0.54$ until $0.08 ; \mathrm{p}=0.149$ ).

The logodd of perceived threats for women of reproductive age with high peer support was 0.18 point higher than that for Women of Reproductive Age with low peer support $(b=0.18 ; 95 \% \mathrm{CI}=-0.13$ until $0.51 ; \mathrm{p}$ $=0.256)$.

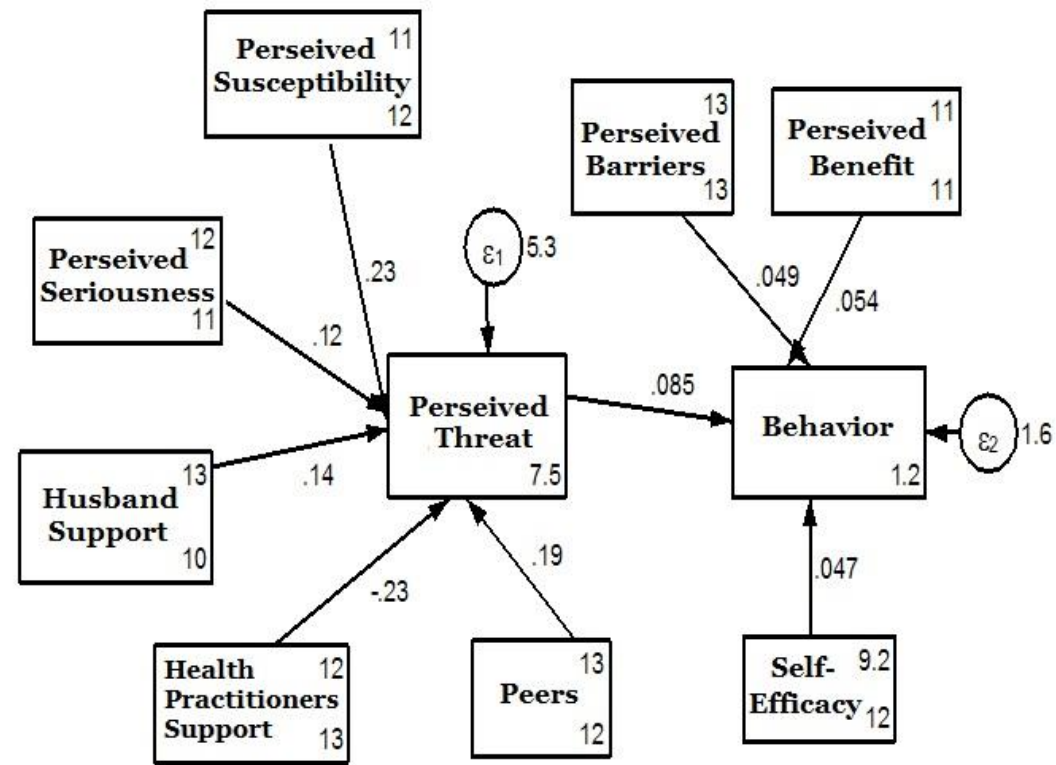

Pictrure 1. The Structural Model with Estimate

Table 5. Results of path analysis for personal factors, husband's support, health workers support and peer support toward the use of acetate acid visual inspection screening among women of reproductive age in the Regency of Karanganyar

\begin{tabular}{|c|c|c|c|c|c|c|}
\hline \multirow{2}{*}{\multicolumn{2}{|c|}{$\begin{array}{l}\text { Independent } \\
\text { Variable }\end{array}$}} & \multirow[b]{2}{*}{ Dependent Variable } & \multirow[b]{2}{*}{$\begin{array}{c}\text { Path } \\
\text { Coefficient }\end{array}$} & \multicolumn{2}{|c|}{ 95\% CI } & \multirow[b]{2}{*}{$\mathbf{p}$} \\
\hline & & & & $\begin{array}{l}\text { Lower } \\
\text { Limit }\end{array}$ & $\begin{array}{l}\text { Upper } \\
\text { Limit }\end{array}$ & \\
\hline \multicolumn{2}{|c|}{ Direct Influence } & \multirow{5}{*}{$\begin{array}{l}\text { High perceived benefits } \\
\text { High perceived obstacles } \\
\text { High self-efficacy }\end{array}$} & \multirow[b]{2}{*}{0.08} & \multirow[b]{2}{*}{0.00} & \multirow[b]{2}{*}{0.01} & \multirow[b]{2}{*}{0.043} \\
\hline IVA use & $\leftarrow$ & & & & & \\
\hline IVA use & $\leftarrow$ & & 0.05 & -0.00 & 0.11 & 0.091 \\
\hline IVA use & $\leftarrow$ & & -0.49 & -0.11 & 0.07 & 0.091 \\
\hline IVA use & $\leftarrow$ & & 0.47 & -0.01 & 0.11 & 0.125 \\
\hline \multicolumn{2}{|c|}{ Indirect Influence } & \multirow{5}{*}{$\begin{array}{l}\text { High perceived susceptibility } \\
\text { - High perceived seriousness } \\
\text { High husband's support }\end{array}$} & \multirow{3}{*}{0.23} & \multirow{3}{*}{0.11} & \multirow{3}{*}{0.34} & \multirow{3}{*}{$<0.001$} \\
\hline High threat & $\leftarrow$ & & & & & \\
\hline High threat & $\leftarrow$ & & & & & \\
\hline \multirow{2}{*}{ High threat } & $\leftarrow$ & & 0.11 & 0.00 & 0.22 & 0.049 \\
\hline & & & 0.14 & -0.01 & 0.29 & 0.068 \\
\hline High threat & $\leftarrow$ & - High health workers support & -0.23 & -0.54 & 0.08 & 0.149 \\
\hline High threat & $\leftarrow$ & - High peer support & 0.18 & -0.13 & 0.51 & 0.256 \\
\hline
\end{tabular}

\section{DISCUSSIONS}

\section{The influence of perceived threats} toward the behavior of using IVA screening

The results of the study show that there has been direct and statistically significant inf- luence from perceived threats toward the behavior of using IVA screening. Individual perception regarding the possibility of suffering from a disease (perceived susceptibility) cause individuals to immediately feel threatened. Individual view regarding the 
Journal of Health Promotion and Behavior (2017), 2(2): 124-137

https://doi.org/10.26911/thejhpb.2017.02.02.03

severity of the disease (perceived seriousness) refers to the risks and the difficulties that he or she might have when the individual suffer from the disease, This situation will encourage individuals to perform preventive or curing actions (Noorkasiani, 2009).

The results of this study are in accordance to a study by Rosser et al. (2015) which concluded that perceived threats have significant relationship to the behavior of using IVA screening.

\section{The influence of perceived bene- fits toward the behavior of using IVA screening}

The results of the analysis show that there has been direct and statistically non-significant influence from perceived benefits toward the behavior of using IVA screening. An individual who perceives that an action might have value or benefit in decreasing a risk will tend to perform the action, in this case the behavior of using IVA screening.

The theory of Health Belief Model states that the performance of both preventive and curing actions will be influenced by perceived benefits, namely a perception regarding the benefits of performing an action. The higher the motivation is the more positive the perceived benefits will be. Support, knowledge and also experience in relation to an individual's perceived benefits are important. Support is an important determinant for individuals in performing a behavior. Individuals who have high support tend to have high perceived benefits, to be responsible in their role and to be socially active (Rosenstock, 1982).

The results of this study are in accordance to a study by Ibekwe et al. (2010) which conclude that perceived benefits are not significantly related to the behavior of using IVA screening and to a study by Welcen (2010) which conclude that percei- ved benefits are not significantly related to behaviors.

The results of this study are also in accordance to a study by Oktaviana (2015) which mentioned that perceived benefits have statistically significant relationship to the behavior of using IVA screening. This statement implied that the more individuals perceive the benefits in performing an action in order to avoid a disease the more inclined the individuals will perform the action. The statement is also supported by the theory of HBM that had been developed by Rosenstock (1994) in which the theory postulated that the effectiveness of trustworthy level toward a strategy that has been devised to decrease the threats of a disease might be higher and individuls therefore might automatically perform the preventive actions, in this case the behavior of using IVA screening.

\section{The influence of perceived obs- tacles toward the behavior of us- ing IVA screening}

The results of the analysis show that there has been negative and direct influence from perceived obstacles toward the behavior of using IVA screening although the influence is statistically insignificant. Limited access to funding, transportational distance and information and technology exacerbate the condition of women who perform IVA screening. If women have access to funding and can make decision independently then they will gain significant impact for their welfare. The situation becomes worse when women with genital area-related diseases do not look for health service because they are afraid of negative social stigma that they will have or they are afraid that their disease has already been in a further stadium (Widihastuti et al., 2013).

The Health Belief Model theory mentions that all concepts of perception, including perceived obstacles, are the determi- 
nant for behavioral changes. In order that the new behavior will be adopted, an individual needs to trust that the benefits of the new behaviors will be greater than those of the old behaviors. The potentially negative aspects in performing health efforts (such as: uncertainly and side effects) or in perceived obstacles (such as: being anxious, being ill-fit, being unhappy and being nervous) might play a role in recommending a behavior. The presence of perceived obstacles in IVA screening method causes individuals, or Women of Reproductive Age, to be unwilling to perform the screening. The reason is that these individuals have negative perceptions due to their lack of understanding toward the benefits of IVA screening or due to the obstacles that the health workers have. Such obstacles might cover tools availability, access to health service and insufficient health service and also health workers (Rosentock, 1982).

The results of this study are in accordance to a study by Ibekwe et al. (2011) which concluded that perceived obstacles are not significantly related to the behavior of using screening.

The results of this study are supported by Were E. et al., (2011) in their study which explained that the most general obstacle in relation to why women do not perform screening is that they do not have enough fund and they are afraid of the screening results; this conclusion was supported by $22.40 \%$ respondents in their study. Then, Widihastuti et al. (2013) also stated that there is still a perception that women have weak access and women are dependent, for example in terms of family finance, so that they have low capabilities to protect themselves from the risk factors of diseases. In the same time, even when they are ill women should ask their husband's permission if they want to afford health service facilities.

\section{The influence of self-efficacy tow- ard the behavior of using IVA screening}

The results of the analysis show that there has been direct but statistically non-significant influence from self-efficacy toward the behavior of using IVA screening. In terms of educational background, from 150 subjects 37 women of reproductive age have high educational background while the remaining Women of Reproductive Age have low educational background.

Individual knowledge is the results of an education that has not only been attained from the formal education but also from the informal education, which increases society's insight. Individual background might influence an individual's attitudes and behaviors based on the knowledge that he or she has. Education might assist improving communication and influencing the process of providing and retrieving information regarding health so that the information might be easily accepted by family members. According to Bloom (1956) in a book entitled Taxonomy of Education $\mathrm{Ob}$ jective, what has been intended by knowledge is the capabilities to recognize and to memorize definitions and is the preliminary factor of expected behaviors which has been positively correlated to behaviors.

Self-efficacy is an individual's belief on his or her capabilities to arrange and to perform something that influence his or her life. Efficacy determines how an individual perceives, thinks, motivates himself and behaves; the source of efficacy is the experience of success, the experience of other people, the social persuasion and the physical-emotional situations. Self-efficacy is related to motivation. Motivation is an important determinant for an individual in order that he or she might perform his or her role well. Individuals who have strong motivation tend to have strong self-efficacy, 
Journal of Health Promotion and Behavior (2017), 2(2): 124-137

https://doi.org/10.26911/thejhpb.2017.02.02.03

to be responsible in their role and to be socially active. Strong motivation causes individuals to put aside the obstacles and to perform their role as optimal as possible. Therefore, the stronger the motivation of women of reproductive age in performing IVA screening is the stronger the selfefficacy that they will have. Based on the results of this study, husband's support, health workers support and peer support are not significant variables so the researchers might conclude that the low support will influence self-efficacy (Bandura, 1994).

The results of the study are in accordance to a study by Lugue et al. (2016) which concluded that self-efficacy is not related significantly to the behavior of using IVA screening.

\section{The influence of perceived sus- ceptibility toward the behavior of using IVA screening}

The results of the analysis showed that there has been indirect but significant influence from perceived susceptibility toward the behavior of using IVA screening in the Regency. Perceived susceptibility refers to a strong perception that an individual will adopt healthy behaviors. This study show that women of reproductive age in the Regency of Karanganyar perceives that they are susceptible to suffer from cervix cancer so that they perform preventive action by means of screening and vice versa. This finding is in accordance to the theory of Health Belief Model which states that an individual who easily suffers from a disease will find protection.

If an individual feels susceptible to suffer from a disease, then he or she will display safe behaviors and take preventive actions (Hayden, 2010). According to Rosenstock (1982) and Noorkasiani (2009), they who feel susceptible to suffer from a disease will immediately feel threatened.
This threat encourages individual to take preventive actions or disease treatments.

This study is also in accordance to a study by Wigati (2016), which shows that there has been indirect but significant relationship from perceived susceptibility toward the implementation of IVA test in the City of Kediri $(p=0.016)$. Her study concluded that individuals who have high perceived susceptibility toward cervix cancer will take preventive actions in order to avoid the occurrence of cervix cancer and one of such actions is undergoing IVA test.

6. The influence of perceived seriousness toward the behavior of using IVA screening

The results of the analysis show that there has been statistically significant relationship between perceived seriousness and the behavior of using IVA screening. The more serious or the more severe the disease that an individual has is, the more the individual will be willing to take preventive actions through the use of IVA screening.

This study is in accordance to a study by Oktaviana (2015), which showed that there has been relationship between perceived seriousness and the IVA screening ( $\mathrm{p}$ $=0.009$ ) and there has been a perception or belief regarding the severity of a disease, namely the cervix cancer, that an individual will be willing to perform examination by means of IVA screening method. The reason is that the subjects do not want to suffer from a serious disease and, as a result, they will take preventive actions in order to prevent the occurrence of the disease.

\section{The influence of husband's sup- port toward the behavior of using IVA screening}

The results of the analysis show that there has been statistically insignificant influence from husband's support toward the behavior of using IVA screening. Husband's sup- 
port might be displayed through emotional support, instrumental support, informative support, assessment or appreciation.

The results of this study are in accordance to a study by Kissal et al. (2011), which concluded that husband's support does not have significant relationship to the behavior of using IVA screening

Other results are shown in a stud by Kurniawati (2015), which concluded that there has been influence from husband's support toward the behavior of using IVA screening. From the results of Wald test, she attained significant scores that had been equal to $(\mathrm{p}=0.039)$ and these scores show that there has been influence from husband's support toward the behavior of IVA examination. The value of Odd Ratio in this study for husband's support variable is equal to 3.627 , which implies that mothers or women with good husband's support have 3.627 times higher possibility to perform IVA examination than those with poor husband's support.

\section{The influence of health workers support toward the behavior of using IVA screening}

The results of the analysis showed that there has been indirect and insignificant influence from health workers support toward the behavior of using IVA screening. Health workers have provided emotional/psychological support, appreciation, social integration and informative support. Emotional support might be seen from the health workers who provide encouragements, who display good attitudes and who have warm personality.

Social support does not only provide positive impacts in influencing stress occurrence and impacts. Sarafino (1998) mentions several examples of negative impacts that might be caused by social support, such as not considering the available assistance as something helpful. This might hap- pen because: the support that has been provided is not sufficient; individuals perceive that they do not need assistance or they are so emotionally concerned that they do not pay attention to the support that has been provided; the support that has been provided is not in accordance to what individuals expect; and the sources of support display bad examples for individuals such as performing or suggesting unhealthy behaviors, being too protective or not supporting individuals in performing the activities that they want. These situations might disturb the rehabilitation program that individuals should perform and might also cause individuals to be dependent on other people.

The results of this study are in accordance to a study by Kissal et al. (2011), which concluded that health workers support do not significantly influence the behavior of using IVA screening. Similarly, in this study it is also concluded that the number of people who encourage participation in the screening use, instead of the number of social support for women's participation rate in the examination, perhaps should be improved.

\section{The influence of peer support to- ward the behavior of using IVA screening}

The results of the study showed that there has been indirect and insignificant influence from peer support toward the behavior of using IVA screening.

There are three processes that peers or closed friend have in providing social support. The first process is providing material or instrumental support. Peers or closed friends might support women of reproductive age by providing information regarding the ways to overcome the health problems or by providing the necessary fund. Next, the second process is providing emotional support. Feelings of being depressed 
Journal of Health Promotion and Behavior (2017), 2(2): 124-137

https://doi.org/10.26911/thejhpb.2017.02.02.03

might be decreased by sharing the problems to the sympathetic friends. Dignity might increase, while depression and anxiety might be eliminated through the sincere acceptance by closed friends. Finally, the third process is performing social integration. Becoming part of an activity under a cooperative spare time and accepting individuals in a social group might eliminate the feelings of loneliness and result in the sense of welfare and the strong social bond (Taylor, 2009).

The results of this study are in accordance to a study by Kissal et al. (2011), which concluded that peer support does not have significant relationship to the behavior of using IVA screening.

\section{REFERENCE}

Bandura A (1994). Self-efficacy in Ramachaudran (Ed.) Encyclopedia of human behavior. 4: 71-81. New York: Academic Press.

Dinas Kesehatan Provinsi Jawa Tengah (2015). Profil Kesehatan Provinsi Jawa Tengah Tahun 2015. Semarang: Dinas Kesehatan Provinsi Jawa Tengah.

Ibekwe CM, Hoque ME, Ntuli-Ngcobo B (2010). Perceived Benefits of Cervical Cancer Screening among Women Attending Mahalapye District Hospital, Botswana. Asian Pacific Journal of Cancer Prevention: 11

Ibekwe CM, Hoque ME, Ntuli-Ngcobo B (2011). Perceived Barriers of Cervical Cancer Screening Among Women Attending Mahalapye Distict Hospital, Botswana. iMedPub Journals. 2 (1)

Kemenkes (2015). Pusat Data dan Informasi. Jakarta: Kementerian Keseha$\tan \mathrm{RI}$.

Kemenkes (2015). Buletin Jendela Data dan Informasi. Jakarta: Kementerian Kesehatan RI.
Kemenkes (2015). Rencana Strategis Kementerian Kesehatan RI. Jakarta: Kementerian Kesehatan RI.

Kissal A, Birgul V, Fatma E, Tudba S (2016). The Effect of Women's Breast Cancer Fear and Social Support Perception on the Process of Participating in Screening. IUHPE-Global Health Promotion: 1757-9759

Kurniawati W, Faridah A, sugeng M (2015). Fakto-faktor yang berhubungan dengan Perilaku WUS dalam melakukan deteksi dini kanker serviks dengan metode inspeksi visual asam asetat (IVA) di Wilayah kerja Puskesmas Kretek Bantul.

Lugue JS, Tarasenko YN, Reves-Garcia C, Alfonso ML, Suazo N, Rebing L, Ferris DG (2016). Salud es Vida: a Cervical Cancer Screening Intervention for Rural Latina Immigrant Women. J Cancer Education

Noorkasiani (2009). Sosiologi Keperawatan. Jakarta : Penerbit Buku Kedokteran EGC.

Oktaviana MR. (2015). Hubungan antara persepsi kerentanan individu, keseriusan penyakit, manfaat dan hambatan dengan penggunaan skrining Inspeksi Visual Asam Asetat pada Wanita Usia Subur. Surakarta: Universitas Sebelas Maret

Penney TL, McIsaac JL, Storey K, Kontak J, Ata N, Kuhle S, Kirk SFL (2016). Examining the Context of Health Promoting Schools: a Trasnlational Approach to Characterization and Measurement of School Ethos to Support Health and Wellbeing. BMC Public Health

Rosser JI, Betty N, Megan J, Hucko (2015). Knowledge about Cervical Cancer Screening and Perception of risk among women attending outpatient clinics in rural kenya. International 
Journal of Gynecology \& Obstetrics, 128 (3): 211-215.

Sarafino EP (1998). Health psycology biopsycososial Interactions. Third edition. New York: John Wiley and Sons. Inc

Taylor SE (2011). Social Support: In: Friedman HS, Editor. Oxford book of Health Psychology. New York, New York: Oxford University Press.

Welchen T, Minggen L, Daniel C (2010). Cervical Cancer Screening Among Taiwanese Women: A Transtheoretical Approach. Oncology Nursing Forum. 37 (4).

Were E, Nyaberi Z , Buziba N (2011). Perceptions of risk and barriers to cervical cancer screening at Moi Teaching and Referral Hospital
(MTRH), Eldoret, Kenya. NCBI Journal.

Widihastuti A, et al (2013). Modul Pelatihan Layanan Kesehatan Seksual \& Reproduksi Ramah Remaja untuk Dokter Praktik Swasta di Dearah Istimewa Yogyakarta, Kemitraan UNFPA dan Angsamerah Institution.

Wigati PA (2016). Analisis Jalur dengan health belief model tentang penggunaan skrining inspeksi visual asam asetat untuk deteksi dini kanker serviks pada wanita usia subur. Surakarta: Universitas Sebelas Maret 